\title{
KEBIJAKAN FORMULASI PIDANA TERHADAP KORPORASI SEBAGAI PELAKU TINDAK PIDANA PENCUCIAN UANG DALAM UNDANG-UNDANG NOMOR 8 TAHUN 2010 TENTANG PENCEGAHAN DAN PEMBERANTASAN TINDAK PIDANA PENCUCIAN UANG
}

\author{
Kristian \& Christine Tanuwijaya \\ Dosen di Universitas Kristen Maranatha (UKM) \& Mahasiswa Fakultas \\ Hukum Universitas Kristen Maranatha
}

\begin{abstract}
ABSTRAK
Globalisasi yang ditandai oleh pergerakan yang cepat dari manusia, informasi perdagangan dan modal, di samping menimbulkan manfaat bagi kehidupan manusia juga harus diwaspadai efek sampingnya yang bersifat negatif, yaitu adanya globalisasi kejahatan dan meningkatnya kuantitas serta kualitas kejahatan. Tindak pidana pencucian uang sebagai salah satu bentuk kejahatan transnasional yang tersistematis menuntut negara-negara untuk mengambil tindakan-tindakan pencegahan melalui hukum nasionalnya serta mewajibkan setiap negara untuk mengadopsi sesuai dengan prinsip-prinsip hukum nasionalnya, tindakan-tindakan legislatif dan tindakan-tindakan lain yang diperlukan, untuk menangani kegiatankegiatan yang digolongkan kedalam bentuk tindak pidana pencucian uang (money laundering). Tindak pidana pencucian uang tidak hanya mengancam stabilitas perekonomian dan integritas sistem keuangan, tetapi juga dapat membahayakan sendi-sendi kehidupan bermasyarakat, berbangsa dan bernegara, dewasa ini perkembangannya cukup memprihatinkan. Kejahatan dengan memanfaatkan jaringan sistem keuangan untuk menyembunyikan asal-usul uang dari hasil tindak pidana tertentu agar tampak seperti layaknya uang halal menimbulkan dampak kerugian yang tidak sedikit bahkan dapat bersifat sistemik. Sebagai bentuk kejahatan terusan atas suatu delik tertentu yang menyertainya, kejahatan tersebut butuh sarana atau upaya yang komprehensif dalam penanganannya.

Pelaku tindak pidana dalam tindak pidana pencucian uangpun dapat diklasifikasikan menjadi 2 (dua) yaitu pelaku dalam artian manusia sebagai subjek hukum (pendukung hak dan kewajiban) serta dapat pula berbentuk korporasi.Dalam rangka menanggulangi money laundering terdapat 2 (dua) langkah yang dapat diambil baik upaya penal maupun non penal. Berbicara upaya penal tentunya tidak lepas dari pembicaraan mengenai kebijakan kriminal atau "criminal policy" sebagaimana dikemukakan oleh G.Peter Hoefnagels bahwa "criminal policy is the rational organization of the social reaction to crime". Pada makalah ini pembahasan akan berfokus pada kebijakan hukum pidana terhadap korporasi yang melakukan tindak pidana pencucian uang berdasarkan UndangUndang No. 8 Tahun 2010 tentang Pencegahan dan Pemberantasan Tindak Pidana Pencucian Uang.
\end{abstract}

Kata Kunci: Kebijakan Formulasi, Korporasi, Tindak Pidana Pencucian Uang. 


\begin{abstract}
Globalization characterized by rapid movement of people, trade and capital information, in addition to the beneficial effects for human life must also be wary of negative side effects, namely the globalization of crime and increasing the quantity and quality of crime.Money laundering as a form of transnational and systematic crimerequires states to take precautions through domestic law and require each country to adopt in accordance with the principles of its domestic law, legislative measures and other measures necessary, to handle activities that are classified in the form of money laundering.Money laundering not only threaten economic stability and integrity of the financial system, but also can harm the joints of the life of society, nation and state, today's development is quite alarming.Crime by utilizing the network of financial systems to hide the origin of money from certain criminal offenses to look like lawful money impact is not small losses can even be systemic.The crime of the canal above a certain offense that accompanies it, the crime took means or comprehensive effort in handling. Criminal in money laundering can be classified into 2 (two), namely in terms of human actors as subjects of law (support rights and obligations), and can also form a corporation.In order to tackle money laundering are two (2) steps that can be taken both penal and non-penal efforts. Speaking penal efforts must not be separated from the discussion on criminal policyas proposed by G.Peter Hoefnagels that "criminal policy is the rational organization of the social reaction to crime". In this paper, the discussion will focus on the policy of the criminal law against corporations that make money laundering based on UndangUndang No. 8 Tahun 2010 tentang Pencegahan dan Pemberantasan Tindak Pidana Pencucian Uang.
\end{abstract}

Keywords: Formulation, Corporate, Money Laundering.

\title{
I. PENDAHULUAN.
}

Hukum dalam perkembangannya tidak hanya dipergunakan untuk mengatur tingkah laku yang sudah ada dalam suatu masyarakat dan mempertahankan pola-pola kebiasaan yang telah ada.Lebih jauh dari itu, hukum telah mengarah kepada penggunaanya sebagai suatu sarana atau alat. ${ }^{1}$ Globalisasi yang ditandai oleh pergerakan yang cepat dari manusia, informasi perdagangan dan modal, di samping menimbulkan manfaat bagi kehidupan manusia juga harus diwaspadai efek sampingnya yang bersifat negatif, yaitu globalisasi kejahatan dan meningkatnya kuantitas serta kualitas kejahatan di berbagai negara dan antar

1 Esmi Warrasih Pudji Rahayu, Pranata Hukum Sebuah Telaah Sosiologis, Penerbit PT. Suryandaru Utama, Semarang, 2005, hlm. 20. 
negara. ${ }^{2}$ Menghadapi efek negatif dari globalisasi yaitu peningkatan terhadap kuantitas dan kualitas kejahatan, hukum mengambil peranannya sebagai sarana atau alat untuk mengatur ketertiban umum dan memulihkan keseimbangan dalam kehidupan masyarakat.

Globalisasi sering diartikan sebagai globalisasi di bidang ekonomi, perdagangan dan investasi.Kemajuan dan perkembangan dunia seolah-olah membuat batas-batas negara, kedaulatan dan hak-hak berdaulat menjadi kabur di bidang ekonomi, perdagangan dan investasi.Hal ini lah yang menyebabkan terjadinya berbagai bentuk kejahatan yang bersifat luas hingga melampaui batasbatas yurisdiksi suatu negara. Article 1 United Nations Convention Against Transnational Organized Crime Tahun 2000 (UNCATOC) menentukan bahwa the purpose of this convention is to promote cooperation to prevent and combat transnational organized crime more effectively. ${ }^{3}$ Dilihat dari tujuan tersebut, terbukti adanya keprihatinan masyarakat internasional mengenai kejahatan yang berkembang dewasa ini yang tidak saja merupakan masalah suatu negara, tetapi juga merupakan masalah global.

Suatu kejahatan dapat dipandang sebagai kejahatan transnasional sebagaimana ditentukan dalam Article 3 ayat (2) UNCATOC yaitu: a) It is committed in more than one state; b) It is committed in one state but substansial part of its preparation, planning, direction or control takes place in another state; c) It is committed in one state but involves an organized criminal group that engaged in criminal activities in more than one state; or d) It is committed in one state but has substantial effects in another state (dilakukan di satu Negara namun memiliki akibat utama di Negara lain). ${ }^{4}$

Tindak pidana pencucian uang sebagai salah satu bentuk kejahatan transnasional yang tersistematis menuntut bekerjanya hukum nasional dalam konteks kerjasama internasional sebagaimana yang telah dihimbau oleh The

2 Nyoman Serikat Putra Jaya, Globalisasi HAM dan Penegakan Hukum, Makalah: disampaikan pada matrikulasi mahasiswa program Magister Ilmu Hukum UNDIP Tahun 2010, tanggal 18 September 2010.

3 Article 1 The United Nations Convention Against Transnational Organized Crimes Tahun 2000.

4 The United Nations Convention Against Transnational Organized Crimes, Ibid. Article 3 ayat (2) 
United Nations Convention Against Corruption, 2003 (Konvensi Perserikatan Bangsa-Bangsamenentang Korupsi, 2003) berupa kewajiban negara-negara peserta untuk mengambil tindakan-tindakan pencegahan melalui hukum nasionalnya serta mewajibkan setiap negara untuk mengadopsi sesuai dengan prinsip-prinsip hukum nasionalnya, tindakan-tindakan legislatif dan tindakantindakan lain yang diperlukan, untuk menangani kegiatan-kegiatan yang digolongkan kedalam bentuk tindak pidana pencucian uang (Money Laundering). ${ }^{5}$

Tindak pidana pencucian uang sebagai bentuk kejahatan yang tidak hanya mengancam stabilitas perekonomian dan integritas sistem keuangan, tetapi juga dapat membahayakan sendi-sendi kehidupan bermasyarakat, berbangsa dan bernegara, ${ }^{6}$ dewasa ini perkembangannya cukup memprihatinkan.Kejahatan dengan memanfaatkan jaringan sistem keuangan untuk menyembunyikan asalusul uang dari hasil tindak pidana tertentu agar tampak seperti layaknya uang halal menimbulkan dampak kerugian yang tidak sedikit bahkan dapat bersifat sistemik.Sebagai bentuk kejahatan terusan atas suatu delik tertentuyang menyertainya, kejahatan tersebut butuh sarana atau upaya yang komprehensif dalam penanganannya. ${ }^{7}$

Untuk menanggulangi money laundering terdapat dua jenis langkah yang dapat diambil baik upaya penal maupun non penal. Berbicara upaya penal tentunya tidak lepas dari pembicaraan kebijakan kriminal atau "criminal policy" yang oleh G.Peter Hoefnagels diartikan sebagai "criminal policy is the rational organization of the social reaction to crime". 8 Namun patut dicatat bahwa kebijakan penanggulangan kejahatan dengan sarana "penal" (hukum pidana)

5 Lihat article 14 yang mengatur mengenai Measures To Prevent Moneylaundering dalam The United Nations Convention Against Corruption, 2003 (Konvensi Perserikatan Bangsa-Bangsa menentang Korupsi, 2003).

6 Lihat Konsiderans menimbang huruf (a) dalam Undang-Undang Nomor 8 Tahun 2010 Tentang Pencegahan dan Pemberantasan Tindak Pidana Pencucian Uang.

7 Lihat Pasal 2 Ayat (1) Undang-Undang Nomor 8 Tahun 2010 Tentang Pencegahan dan Pemberantasan Tindak Pidana Pencucian Uang.

8 G. Peter Hoefnagels, The Other Side of Criminology, Kluwer Deventer, Holland, 1973, hlm. 57. 
mempunyai keterbatasan, terlebih menghadapi tindak pidana pencucian uang yang merupakan bagian dari kejahatan lintas negara yang terorganisasi. ${ }^{9}$

Dilihat dari sisi yuridis, masalah utama adalah bagaimana memformulasikan persoalan kesalahan dan pertanggungjawaban pidana dalam produk perundang-undangan sebagaimana yang dikatakan Dennis, "most of the legislation in criminal law has related to specific offences. General principles of criminal liability are largely still the work of the judges". ${ }^{10}$

Berbicara tentang kejahatan tentunya tidak terlepas dari peran serta pelaku atau dader.Pelaku tindak pidana dalam kejahatan pencucian uang dapat diklasifikasikan menjadi 2 (dua) yaitu pelaku dalam artian manusia sebagai subjek hukum pendukung hak dan kewajiban serta dapat pula berbentuk korporasi. ${ }^{11}$ Terlepas dari pro-kontra terhadap pertanggungjawaban korporasi sebagai subjek hukum pidana, Oemar Seno Adji berpendapat, "kemungkinan adanya pemidanaan terhadap persekutuan-persekutuan, didasarkan tidak saja atas pertimbangan-pertimbangan utilitas, melainkan pula atas dasar-dasar teoritis dapat dibenarkan". ${ }^{12}$

Permasalahan tindak pidana pencucian uang yang dalam praktiknya tidak hanya dilakukan individu melainkan juga dilakukan korporasi menimbulkan penyelesaian yang berbeda di antara keduanya dengan melihat unsur kejahatan dan pertanggungjawaban pidana yang menjadi dasar penjatuhan sanksi dalam kasus tindak pidana pencucian uang tersebut.Penanganan secara penal maupun non penal terhadap tindak pidana pencucian uang yang dilakukan korporasi menarik minat penulis untuk melakukan penulisan jurnal dengan judul, "KEBIJAKAN FORMULASI HUKUM PIDANA TERHADAP

9 Barda Nawawi Arief, Kapita Selekta Hukum Pidana, Penerbit PT Citra Aditya Bakti, Bandung, 2010, hlm. 174.

10 Chairul Huda, Dari Tiada Pidana Tanpa Kesalahan Menuju Kepada Tiada Pertanggungjawaban Pidana Tanpa Kesalahan, Prenada Media, Jakarta, 2006, hlm. 2.

11 Lihat Pasal 1 Angka 9 Undang-Undang Nomor 8 Tahun 2010 Tentang Pencegahan dan Pemberantasan Tindak Pidana Pencucian Uang.

12 Oemar Seno Adji dalam Setiyono, Kejahatan Korporasi Analisis Viktimologis Dan Pertanggungjawaban Korporasi Dalam Hukum Pidana Indonesia, Bayu Media Publishing, Malang, 2005. hlm. 11. 


\section{KORPORASI SEBAGAI PELAKU TINDAK PIDANA PENCUCIAN UANG DALAM UNDANG-UNDANG NOMOR 8 TAHUN 2010".}

Dari latar belakang penulisan di atas, adapun permasalahan yang akan dibahas dalam makalah ini adalah sebagai berikut:

1. Bagaimana kebijakan formulasi hukum pidana terhadap tindak pidana pencucian uang ?

2. Bagaimana pola pertanggungjawaban korporasi sebagai pelaku tindak pidana pencucian uang?

\section{PEMBAHASAN.}

\section{A. Kebijakan Formulasi Hukum Pidana Terhadap Tindak Pidana Pencucian Uang.}

Kebijakan formulasi hukum pidana diartikan sebagai suatu usaha untuk membuat dan merumuskan suatu perundang-undangan pidana yang baik. Pengertian tersebut terlihat pula dalam defenisi yang dikemukakan oleh Marc Ancel yang menyatakan bahwa penal policy sebagai suatu ilmu sekaligus seni yang bertujuan untuk memungkinkan peraturan hukum positif dirumuskan secara lebih baik dan untuk memberi pedoman tidak hanya kepada pembuat Undang-Undang, tetapi juga kepada pengadilan yang menerapkan Undang-Undang dan juga kepada para penyelenggara atau pelaksana putusan pengadilan. ${ }^{13}$

Memperhatikan alasan penting di atas, maka penggunaan pidana dan hukum pidana diperlukan dalam rangka penanganan terhadap tindak pidana pencucian uang sekaligus untuk memulihkan sendi-sendi kehidupan sosial yang terganggu oleh adanya kejahatan yang bertentangan dengan semangat hidup berbangsa dan bernegara tersebut.

Berbicara mengenai kebijakan formulasi hukum pidana, tentunya tidak terlepas dari objek yang hendak diatur yaitu kejahatan atau strafbaarfeit, Simons mengatakan bahwa strafbaarfeit itu adalah kelakuan yang diancam dengan pidana, bersifat melawan hukum, dan berhubung dengan kesalahan yang dilakukan oleh

13 Barda Nawawi Arief, Bunga Rampai Kebijakan Hukum Pidana (Perkembangan Penyusunan Konsep KUHP Baru), Kencana, Jakarta, 2008, hlm. 80. 
orang yang mampu bertanggung jawab. Simons menekankan bahwa meskipun betul harus diakui bahwa tidak selalu perbuatan yang mencocoki rumusan delik dalam wet adalah bersifat melawan hukum, akan tetapi perkecualian yang demikian itu hanya boleh diterima apabila mempunyai dasar dalam hukum positif sendiri". ${ }^{14}$

Simons juga menyatakan bahwa apabila sifat melawan hukum dari suatu tindakan itu diragukan, maka hakim tidak boleh menyatakan kesalahan dari tertuduh sebagai terbukti. Sifat melawan hukum dari suatu tindakan itu timbul dari keadaan di mana tindakan tersebut ternyata telah melanggar sesuatu peraturan yang bersifat melarang, dan hanyalah menjadi hapus apabila orang itu dapat menunjukkan sesuatu dasar yang meniadakan sifat tersebut di dalam peraturan itu sendiri". 15

Adanya unsur perumusan dalam undang-undang dan pertanggungjawaban pidana merupakan ciri mendasar dari definisi kejahatan atau perbuatan pidana menurut Simmons dan Van Hammel.Selanjutnya menurut Indriyanto Seno Adji tindak pidana adalah perbuatan seseorang yang diancam pidana, perbuatannya bersifat melawan hukum, terdapat suatu kesalahan dan bagi pelakunya dapat dipertanggungjawabkan perbuatannya. ${ }^{16}$

Berdasarkan beberapa definisi di atas maka terhadap kegiatan pencucian uang dapat dikatakan telah memenuhi unsur-unsur kejahatan yang patut diancamkan pidana oleh karena secara sederhana pengertian pencucian uang dapat diartikan suatu perbuatan memindahkan, menggunakan atau melakukan perbuatan lainnya atas hasil dari suatu tindak pidana yang kerap dilakukan oleh criminal organization, maupun individu yang melakukan tindakan korupsi, perdagangan narkotika, kejahatan kehutanan, kejahatan lingkungan hidup dan tindak pidana lainnya dengan tujuan menyembunyikan, menyamarkan atau mengaburkan asalusul uang yang berasal dari hasil tindak pidana tersebut, sehingga dapat digunakan seolah-olah sebagai uang yang sah tanpa terdeteksi bahwa aset tersebut berasal

14 Indriyanto Seno Adji, Tindak Pidana Ekonomi, Bisnis dan Korupsi Perbankan, Program Pascasarjana Magister Ilmu Hukum Universitas Padjadjaran Bandung, 2004, hlm. 47.

15 Ibid.

16 Chairul Huda, Op Cit, hlm. 26. 
dari kegiatan yang ilegal. ${ }^{17}$ Sehingga terhadap kejahatan tersebut membutuhkan penanggulangan hukum yang tepat.

Pemerintah Indonesia bersama dengan Dewan Perwakilan Rakyat dalam rangka penanggulangan kejahatan money laundering telah membentuk beberapa produk hukum untuk menangani persoalan pencucian uang diantaranya UndangUndang Nomor 15 Tahun 2002 yang telah diubah dengan Undang-Undang Nomor 25 Tahun 2003 tentang Pemberantasan Tindak Pidana Pencucian Uang, dan terakhir diubah dengan Undang-Undang Nomor 8 Tahun 2010 tentang Pencegahan dan Pemberantasan Tindak Pidana Pencucian Uang.

Melihat daripada kenyataan yang terjadi di lapangan, maka pembuat kebijakan melakukan upaya perbaikan formulasi terhadap peraturan perundangundangan sebelumnya.Terdapat beberapa hal yang menarik dari munculnya undangundang baru tersebut yaitu:

a. Adanya redefinisi pengertian hal yang terkait dengan tindak pidana Pencucian Uang, penyempurnaan kriminalisasi tindak pidana Pencucian Uang, pengaturan mengenai penjatuhan sanksi pidana dan sanksi administratif, pengukuhan penerapan prinsip mengenali Pengguna Jasa, perluasan Pihak Pelapor, penetapan mengenai jenis pelaporan oleh penyedia barang dan/atau jasa lainnya, penataan mengenai Pengawasan Kepatuhan, pemberian kewenangan kepada Pihak Pelapor untuk menunda Transaksi, perluasan kewenangan Direktorat Jenderal Bea dan Cukai terhadap pembawaan uang tunai dan instrumen pembayaran lain ke dalam atau ke luar daerah pabean, pemberian kewenangan kepada penyidik tindak pidana asal untuk menyidik dugaan tindak pidana Pencucian Uang, perluasan instansi yang berhak menerima hasil analisis atau pemeriksaan PPATK, penataan kembali kelembagaan PPATK, penambahan kewenangan PPATK, termasuk kewenangan untuk menghentikan

17 Yunus Husein, Peran PPATK Dalam Mendeteksi Pencucian Uang, Makalah: Disampaikan pada acara Video Confrence Nasional yang diselenggarakan oleh Pusat Pelaporan dan Analisis Transaksi Keuangan (PPATK), Bank Indonesia, Universitas Indonesia, Universitas Gadjah Mada, Universitas Sumatera Utara, Universitas Diponegoro, Universitas Airlangga, pada tanggal 18 Mei 2004 di gedung Pasca Sarjana Fakultas Hukum Universitas Indonesia. 
sementara Transaksi, penataan kembali hukum acara pemeriksaan tindak pidana Pencucian Uang; dan pengaturan mengenai penyitaan Harta Kekayaan yang berasal dari tindak pidana;

b. Kebijakan penanggulangan kejahatan dengan sarana penal (dengan menggunakan sarana hukum pidana) bersifat terbatas. ${ }^{18}$ Meskipun Undang-Undang Nomor 8 Tahun 2010 mencantumkan 2 (dua) jenis sanksi baik pidana maupun administratif serta mengadopsi beberapa ketentuan yang terkandung dalam berbagai instrument internasional mengenai penanganan terhadap transaksi keuangan mencurigakan, tetap saja butuh penanganan yang bersifat kompleks dan dapat mengikuti perkembangan laju teknologi.

Tahapan-tahapan dalam proses pencucian uang tersebut dapat digambarkan sebagai berikut:

a. Placement, berupa upaya menempatkan uang tunai yang berasal dari tindak pidana ke dalam sistem keuangan (financial system) atau menempatkan uang giral kembali ke dalam sistem keuangan terutama perbankan;

b. Layering, berupa kegiatan mentransfer harta kekayaan yang berasal dari tindak pidana yang telah berhasil ditempatkan pada penyedia jasa keuangan sebagai hasil upaya Placement ke penyedia jasa keuangan yang lain;

c. Integration, yaitu upaya menggunakan harta kekayaan yang berasal dari tindak pidana yang telah berhasil masuk ke dalam sistem keuangan melalui penempatan atau transfer sehingga seolah-olah menjadi harta kekayaan yang halal.

Meskipun Undang-Undang Nomor 8 Tahun 2010 menggantikan UndangUndang yang telah ada sebelumnya, namun dalam kenyataannya masih terdapat beberapa ketentuan yang menyimpang dari Kitab Undang-Undang Hukum Pidana (KUHP) sebagai pedoman utamanya. Penyimpangan atau perbedaan itu, meliputi beberapa hal berikut ini: a) Adanya subjek tindak pidana berupa "korporasi" dan

18 Barda Nawawi Arief, Kapita Selekta Hukum Pidana, Op Cit, hlm. 174. 
ketentuan khusus mengenai pertanggungjawaban korporasi, (Pasal 6-9 UndangUndang Nomor 8 Tahun 2010); b) Adanya perumusan ancaman pidana secara kumulasi, yaitu penggabungan antara pidana penjara dengan denda; c) Dipidananya percobaan, pembantuan dan permufakatan jahat yang sama dengan pelaku (Pasal 10); dan c) Meningkatnya jumlah ancaman pidana denda yang sangat tinggi, hingga mencapai ketentuan denda maksimal seratus milyar rupiah terhadap pelaku pencucian uang berupa korporasi. ${ }^{19}$

Hal inilah yang dapat menimbulkan masalah yuridis dan kesulitan atau kejanggalan dalam praktik penegakan hukumnya. ${ }^{20}$ Selayaknya pembuat kebijakan memahami mengenai pola pemidanaan yaitu acuan, pegangan atau pedoman untuk membuat atau menyusun peraturan perundang-undangan yang mengandung sistem sanksi pidana, atau juga disebut sebagai pedoman pembuatan atau penyusunan pidana untuk pembuat undang-undang.

\section{B. Pertanggungjawaban Korporasi dalam Tindak Pidana Pencucian Uang.}

Pengertian korporasi merupakan terminologi yang berkaitan erat dengan istilah badan hukum (rechtpersoon), dan badan hukum itu sendiri merupakan terminologi yang erat kaitannya dengan bidang hukum perdata. ${ }^{21}$ Memang peraturan hukum memperlakukan sama, hubungan antara badan hukum dengan manusia, antara badan hukum dengan badan hukum lainnya, seperti hubungan antara manusia dengan manusia. Hukum tidak membedakan, tidak pula membuat peraturan khusus bagi hubungan tertentu.Jadi dalam hukum, badan hukum mempunyai kepentingan (interest) sendiri sebagaimana ada pada manusia.Kepentingannya dilindungi hukum, dan dilengkapi dengan suatu aksi, jika kepentingan itu diganggu.

19 Barda Nawawi Arief, Kapita Selekta Hukum Pidana, Op.Cit, hlm.182. dengan perubahan berdasarkan ketentuan dalam Undang-Undang Nomor 8 Tahun 2010 tentang Pencegahan dan Pemberantasan Tindak Pidana Pencucian Uang.

Ibid.

21 Dwidja Priyatno, Kebijakan Legislasi Tentang Sistem Pertanggungjawaban Pidana Korporasi di Indonesia, Penerbit CV. Utomo, Bandung, 2004, hlm. 12. 
Kondisi saat ini tidak dapat diingkari lagi bahwa korporasi memiliki identitas hukum tersendiri, yang terpisah dari pemegang saham, direktur dan para pejabat korporasi lainnya.Korporasi dapat menguasai kekayaan, mengadakan kontrak, dapat menggugat dan dapat pula digugat.Pemilik atau pemegang saham dapat menikmati tanggung jawab terbatas (limited liability), mereka tidak secara personal bertanggung jawab atas utang atau kewajiban korporasi. Dengan pendekatan teori organik (organic theory) maka tanggung jawab yang sebenarnya dari korporasi terletak pada struktur organisasionalnya, kebijakannya dan kultur yang diterapkan dalam korporasi. ${ }^{22}$

Dewasa ini keberadaan korporasi semakin mendapatkan posisi penting dalam dinamika kehidupan suatu negara, korporasi memegang sektor penting terutama yang berkaitan dengan sektor industri atau ekonomi. Kondisi tersebut di satu pihak membawa dampak positif namun dalam lain hal perkembangan tersebut mendorong munculnya jenis kejahatan ekonomi, atau kejahatan bisnis atau kejahatan korporasi yang dapat diartikan sebagai :

"Illegal acts thet use deceit and concealment-rather than the application or threat of physical force or violence to obtain money, property, service; to avoid the payment or loss of money; or to scour a bussines or professional advantage. White collar accupy positions of responsibility and trust in government, industry, the professions and organizations". ${ }^{23}$

Dari definisi tersebut dapat dilihat bahwa motif utama kejahatan korporasi adalah terletak pada pemenuhan atas motif ekonomi yang berupa keuntungan atau profit yang dilakukan secara illegal atau melawan hukum. Adapun batas-batas mengenai kejahatan korporasi adalah sebagai berikut:

a. Kejahatan tersebut merupakan bentuk kejahatan white collar crime, yaitu kejahatan yang dilakukan oleh orang-orang yang memiliki kedudukan sosial yang tinggi dan terhormat dalam pekerjaannya (crime commited by person of respectability and high social status in the course of their occupation);

22 Nyoman Serikat Putra Jaya, Op Cit, hlm. 93.

23 Podgor dalam Nyoman Serikat Putra Jaya, Kejahatan Dan Pertanggungjawaban Korporasi, Makalah Bahan Kuliah Magister IImu Hukum UNDIP. 
b. Berbentuk kejahatan dengan menggunakan jabatan atau Occupational Crimes, berupa kejahatan yang mengandung dua elemen. Pertama berkaitan dengan status pelaku tindak pidana (status of offender), dan kedua berkaitan dengan karakter jabatan tertentu (the occupation character of the offence);

c. Kejahatan tersebut berbentuk kejahatan yang terorganisir Organized Crime, kejahatan tersebut dikendalikan oleh suatu kesatuan yang lebih besar dalam lingkungan penjahat secara terstruktur dan tersistematis berdasarkan peran dan bagian dari masing-masing anggota kesatuan tersebut. $^{24}$

Proses globalisasi dan peningkatan interdependensi antar negara di semua aspek kehidupan terutama bidang ekonomi semakin meningkatkan peran korporasi, baik nasional maupun multinasional sebagai pendorong dan penggerak globalisasi. Untuk itu dibutuhkan suatu rancang bangun hukum dan kode etik yang dapat mengatur keberadaan korporasi tersebut. Di Indonesia sendiri terkait dengan keberadaan korporasi dalam sektor ekonomi terdapat beberapa peraturan perundang-undangan yaitu sebagai berikut: Undang-Undang Nomor 7 Tahun 1992 Jo. Undang-Undang No. 10 Tahun 1998 Tentang Perbankan, UndangUndang Nomor 31 Tahun 1999 Jo. Undang-Undang Nomor 20 Tahun 2001 Tentang Pemberantasan Tindak Pidana Korupsi, dan Undang-Undang Nomor 8 Tahun 2010 Tentang Pencegahan dan Pemberantasan Tindak Pidana Pencucian Uang. Dari beberapa perundang-undangan tersebut maka dapat disimpulkan bahwa: penentuan korporasi sebagai subjek tindak pidana hanya untuk tindak pidana tertentu yang diatur dengan menggunakan undang-undang khusus, pada awalnya tidak digunakan istilah korporasi tetapi digunakan istilah yang bermacam-macam atau bervariasi (tidak seragam), dan tidak konsisten. ${ }^{25}$

Memperhatikan Undang-Undang Nomor 8 Tahun 2010 sebagai pengganti atas Undang-Undang Nomor 25 Tahun 2003 Tentang Pencegahan dan

24 Setiyono, Op Cit, hlm. 35-37.

25 Barda Nawawi Arief, Op Cit. 
Pemberantasan Tindak Pidana Pencucian Uang, mengenai korporasi diatur sebagai berikut:

\section{Pasal 6}

(1) Dalam hal tindak pidana Pencucian Uang sebagaimana dimaksud dalam Pasal 3, Pasal 4, dan Pasal 5 dilakukan oleh Korporasi, pidana dijatuhkan terhadap Korporasi dan/atau Personil Pengendali Korporasi.

(2) Pidana dijatuhkan terhadap Korporasi apabila tindak pidana Pencucian Uang:

a. dilakukan atau diperintahkan oleh Personil Pengendali Korporasi;

b. dilakukan dalam rangka pemenuhan maksud dan tujuan Korporasi;

c. dilakukan sesuai dengan tugas dan fungsi pelaku atau pemberi perintah; dan

d. dilakukan dengan maksud memberikan manfaat bagi Korporasi.

\section{Pasal 7}

(1) Pidana pokok yang dijatuhkan terhadap Korporasi adalah pidana denda paling banyak Rp.100.000.000.000,00 (seratus miliar rupiah).

(2) Selain pidana denda sebagaimana dimaksud pada ayat (1), terhadap Korporasi juga dapat dijatuhkan pidana tambahan berupa:

a. pengumuman putusan hakim;

b. pembekuan sebagian atau seluruh kegiatan usaha Korporasi;

c. pencabutan izin usaha;

d. pembubaran dan/atau pelarangan Korporasi;

e. perampasan aset Korporasi untuk negara; dan/atau

f. pengambilalihan Korporasi oleh negara.

\section{Pasal 8}

Dalam hal harta terpidana tidak cukup untuk membayar pidana denda sebagaimana dimaksud dalam Pasal 3, Pasal 4, dan Pasal 5, pidana denda tersebut diganti dengan pidana kurungan paling lama 1 (satu) tahun 4 (empat) bulan.

\section{Pasal 9}

(1) Dalam hal Korporasi tidak mampu membayar pidana denda sebagaimana dimaksud dalam Pasal 7 ayat (1), pidana denda tersebut diganti dengan perampasan Harta Kekayaan milik Korporasi atau Personil Pengendali Korporasi yang nilainya sama dengan putusan pidana denda yang dijatuhkan.

(2) Dalam hal penjualan Harta Kekayaan milik Korporasi yang dirampas sebagaimana dimaksud pada ayat (1) tidak mencukupi, pidana kurungan pengganti denda dijatuhkan terhadap Personil Pengendali Korporasi dengan memperhitungkan denda yang telah dibayar.

Dalam Undang-Undang ini korporasi memiliki pertanggungjawaban yang sama dengan individu (natuur person) oleh karena kedudukannya sebagai (recht 
person). Hal ini terlihat dari ketentuan yang mengatakan bahwa : "Dalam hal tindak pidana pencucian uang sebagaimana dimaksud dalam Pasal 3, 4 dan 5 dilakukan oleh korporasi, pidana dijatuhkan terhadap korporasi atau personil pengendali korporasi". Perbuatan sebagaimana diancamkan dalam Pasal 3, 4 dan 5 merupakan perbuatan yang diancamkan terhadap manusia (unsur setiap orang), pencantuman korporasi sebagai subjek tindak pidana dapat dikatakan merupakan penyimpangan dari ketentuan dalam Kitab Undang-Undang Hukum Pidana (KUHP) walaupun hal ini dapat dibenarkan secara yuridis namun dapat mengakibatakan permasalahan dalam proses penegakannya ${ }^{26}$, sementara apabila diperhatikan dalam konsep atau rancangan KUHP Tahun 2013 terdapat peraturan mengenai korporasi sebagai subjek tindak pidana.

Konsep atau rancangan KUHP Tahun 2013 disebutkan dengan tegas bahwa korporasi merupakan subjek tindak pidana. Rancangan KUHP Tahun 2013 juga menyatakan bahwa suatu tindak pidana dilakukan oleh korporasi jika dilakukan oleh orang-orang yang mempunyai kedudukan fungsional dalam struktur organisasi korporasi yang bertindak untuk dan atas nama korporasi atau demi kepentingan korporasi, berdasarkan hubungan kerja atau berdasarkan hubungan lain, dalam lingkup usaha korporasi tersebut, baik sendiri-sendiri atau bersama-sama. Selanjutnya, dalam konsep atau rancangan KUHP Tahun 2013 juga dicantumkan mengenai unsur pertanggungjawaban korporasi yang berbunyi jika tindak pidana dilakukan oleh korporasi, pertanggungjawaban pidana dikenakan terhadap korporasi dan/atau pengurusnya.

Selanjutnya secara berturut-turut dalam Pasal 50 dan Pasal 51 Konsep KUHP Tahun 2013 dicantumkan pertanggungjawaban korporasi sebagai berikut, Korporasi dapat dipertanggungjawabkan secara pidana terhadap suatu perbuatan yang dilakukan untuk dan/atau atas nama korporasi, jika perbuatan tersebut termasuk dalam lingkup usahanya sebagaimana ditentukan dalam anggaran dasar atau ketentuan lain yang berlaku bagi korporasi yang bersangkutan. Pertanggungjawaban pidana pengurus korporasi dibatasi sepanjang pengurus mempunyai kedudukan fungsional dalam struktur organisasi korporasi.

26 Barda Nawawi Arief, Ibid, hlm. 182. 
Terkait dengan sistem pertanggungjawaban pidana korporasi, konsep atau rancangan KUHP Tahun 2013 juga menyatakan bahwa dalam mempertimbangkan suatu tuntutan pidana, harus dipertimbangkan apakah bagian hukum lain telah memberikan perlindungan yang lebih berguna daripada menjatuhkan pidana terhadap suatu korporasi. Pertimbangan tersebut harus dinyatakan dalam putusan hakim. Dalam Pasal 53 konsep KUHP Tahun 2013, dikemukakan bahwa alasan pemaaf atau alasan pembenar yang dapat diajukan oleh pembuat yang bertindak untuk dan/atau atas nama korporasi, dapat diajukan oleh korporasi sepanjang alasan tersebut langsung berhubungan dengan perbuatan yang didakwakan kepada korporasi. Selanjutnya, dalam ketentuan Pasal 85 konsep KUHP Tahun 2013, dikemukakan bahwa jika pengambilan kekayaan atau pendapatan sebagaimana dimaksud dalam Pasal 82 ayat (2) tidak dapat dilakukan maka untuk korporasi dikenakan pidana pengganti denda berupa pencabutan izin usaha atau pembubaran korporasi.

Dengan memperhatikan sistem pertanggungjawaban pidana korporasi yang ada dalam konsep atau rancangan KUHP Tahun 2013 diatas dan dikaitkan dengan sistem pertanggungjawaban pidana korporasi yang ada dalam UndangUndang Nomor 8 Tahun 2010 Tentang Pencegahan dan Pemberantasan Tindak Pidana Pencucian Uang, penulis berkesimpulan bahwa baik dalam UndangUndang Nomor 8 Tahun 2010 Tentang Pencegahan dan Pemberantasan Tindak Pidana Pencucian Uang maupun dalam konsep atau rancangan KUHP Tahun 2013 korporasi telah diakui sebagai subjek hukum pidana, pada kedua undang-undang ini juga dapat dilihat alternatif sanksi yang dapat dijatuhkan manakala korporasi tidak dapat membayar pidana denda (sanksi tidak dirumuskan tunggal). Namun demikian, perlu disadari bahwa dalam konsep KUHP Tahun 2013, pidana pokok yang diancamkan terhadap suatu korporasi yang melakukan tindak pidana adalah pidana denda dan kerja sosial. Pidana tambahan yang dapat dijatuhkan terhadap suatu korporasi diatur dalam Pasal 67 yang menyatakan bahwa pidana tambahan terdiri dari pencabutan hak tertentu, perampasan barang tertentu dan/atau tagihan, pengumuman putusan hakim, pembayaran pengganti kerugian dan pemenuhan kewajiban adat setempat atau kewajiban menurut hukum yang hidup dalam 
masyarakat. Sedang pidana pengganti denda menurut konsep KUHP Tahun 2013 berupa pencabutan izin usaha atau pembubaran korporasi.

Undang-Undang Nomor 8 Tahun 2010 tentang Pencegahan dan Pemberantasan Tindak Pidana Pencucian Uang, perumusan pidana tambahan bagi suatu korporasi yang melakukan tindak pidana diformulasikan dengan lebih baik dan lebih spesifik yakni dengan mengatur mengenai: pengumuman putusan hakim, pembekuan sebagian atau seluruh kegiatan usaha Korporasi, pencabutan izin usaha, pembubaran dan/atau pelarangan Korporasi, perampasan aset Korporasi untuk negara; dan/ataupengambilalihan Korporasi oleh negara.

Selanjutnya, apabila diperhatikan mengenai model-model pertanggungjawaban tentang korporasi sebagai sebagai pembuat suatu delik atau tindak pidana tertentu, terdapat 3 (tiga) model pertanggungjawaban pidana korporasi yaitu sebagai berikut: a) Pengurus korporasi sebagai pembuat dan penguruslah yang bertanggung jawab; b) Korporasi sebagai pembuat dan pengurus yang bertanggung jawab; dan c) Korporasi sebagai pembuat dan juga sebagai yang bertanggung jawab. ${ }^{27}$

Menambahkan 3 (tiga) model pertanggungjawaban pidana korporasi diatas, menurut hemat penulis, model pertanggungjawaban pidana korporasi harus ditambah 1 (satu) model lagi yaitu pengurus dan korporasi sebagai pembuat dan keduanya harus bertanggungjawab. Dikaitkan dengan tindak pidana pencucian uang yang dilakukan, dengan demikian, terhadap korporasi yang melakukan perbuatan berupa Placement, Layering dan Integration, harus terlebih dahulu dibuktikan apakah perbuatan yang tergolong tindak pidana pencucian uang tersebut dilakukan oleh individu secara pribadi ataukah mengatasnamakan pengurus atau korporasi yang bersangkutan, menguntungkan diri sendiri atau menguntungkan suatu korporasi, harus pula dibuktikan bahwa orang yang melakukan tindak pidana pencucian uang tersebut adalah senior officer atau directing mind dari suatu korporasi sehingga perbuatannya dapat dikualifikasikan sebagai perbuatan dari korporasi dan dijatuhkan sanksi sesuai dengan kualifikasinya masing-masing.

27 Dwidja Priyatno, Op Cit, hlm. 53. 
Selanjutnya mengenai persoalan jenis pidana dan pemidanaan, dalam Pasal 7 Undang-Undang Nomor 8 Tahun 2010, diatur mengenai beberapa jenis pidana yang secara garis besar digolongkan kedalam 2 (dua) bagian yaitu pidana pokok berupa denda dan pidana tambahan. Hal yang menarik adalah dicantumkannya mengenai pidana kurungan pengganti denda (Pasal 8) maksimal selama 1 (satu) tahun 4 (empat) bulan yang dapat dijatuhkan terhadap pengurus atau pengendali korporasi disamping itu dalam Pasal 9 ayat (2) dikatakan,dalam hal penjualan Harta Kekayaan milik Korporasi yang dirampas sebagaimana dimaksud pada ayat (1) tidak mencukupi, pidana kurungan pengganti denda dijatuhkan terhadap Personil Pengendali Korporasi dengan memperhitungkan denda yang telah dibayar. Persoalan bagaimana penjatuhan pidana kurungan pengganti denda tersebut dapat dilaksanakan, termasuk mengenai perhitungan kekayaan korporasi yang dirampas sebagai alasan pengurangan pidana kurungan pengganti denda tidak diatur lebih lanjut dalam penjelasan undang-undang tersebut.Hal ini menunjukkan keserampangan dari pembuat kebijakan perundang-undangan dalam merumuskan Undang-Undang Nomor 8 Tahun 2010.

Korporasi sebagai badan hukum merupakan subjek hukum pendukung hak dan kewajiban. Kejahatan korporasi yang selalu berhubungan dengan kegiatan ekonomi atau dunia bisnis dikarenakan pengaruh dari globalisasi yang bersifat multidimensional. Diancamkannya pidana terhadap korporasi sebagai pelaku tindak pidana pencucian uang didasarkan adanya pandangan korporasi sebagai (persoon) dalam artian hukum. Korporasi berbuat dan bertindak atas kepentingan dari korporasi melalui struktur kepengurusan yang tersistematisasi, atas dasar pandangan tersebut dan dengan didukung beberapa teori seperti Strict Liability dan Vicarious Liability maka korporasi dapat dikenakan pidana sebagaimana yang diancamkan dalam Undang-Undang Nomor 8 Tahun 2010 tentang Pencegahan dan Pemberantasan Tindak Pidana Pencucian Uang. 


\section{PENUTUP.}

\section{A. Kesimpulan.}

Berdasarkan pembahasan di atas maka dapat ditarik kesimpulan sebagai berikut:

1. Terdapat beberapa kelemahan formulasi dalam Undang-Undang Nomor 8 Tahun 2010 tentang Pencegahan dan Pemberantasan Tindak Pidana Pencucian Uang, terutama yang berkaitan dengan pidana terhadap korporasi, adanya pidana kumulatif, semakin meningkatnya jumlah dalam denda pidana, dipidananya percobaan dan permufakatan jahat sama halnya dengan pidana penuh.

2. Pertanggungjawaban korporasi terhadap setiap bentuk kegiatan korporasi didasarkan pandangan akan kedudukan korporasi sebagai (recht persoon), dalam Undang-Undang Nomor 8 Tahun 2010 tentang Pencegahan dan Pemberantasan Tindak Pidana Pencucian Uang diatur mengenai pertanggungjawaban korporasi selayaknya individu yang melakukan perbuatan tindak pidana pencucian uang, meskipun dalam formulasinya masih terdapat beberapa kelemahan. Namun demikian, perlu disadari bahwa baik dalam Undang-Undang No. 8 Tahun 2010 Tentang Pencegahan dan Pemberantasan Tindak Pidana Pencucian Uang maupun dalam konsep atau rancangan KUHP Tahun 2013 korporasi telah diakui sebagai subjek hukum pidana. Dalam kedua undang-undang ini juga dapat dilihat alternatif sanksi yang dapat dijatuhkan manakala korporasi tidak dapat membayar pidana denda (sanksi tidak dirumuskan tunggal).

\section{B. Saran.}

Adapun saran yang dapat penulis paparkan dalam penulisan ini adalah sebagai berikut:

1. Pentingnya formulasi kebijakan perundang-undangan dengan memperhatikan pola pemidanaan, agar kebijakan tersebut dapat selaras dalam tataran aplikatif penegakan hukum. Pentingnya pola pemidanaan khususnya dalam Undang-Undang Nomor 8 Tahun 2010tentang Pencegahan dan Pemberantasan Tindak Pidana Pencucian Uang untuk 
menghindarkan permasalahan-permasalahan yuridis yang mungkin timbul dalam proses implementasi kebijakan tersebut.

2. Formulasi pertanggungjawaban pidana korporasi hendaknya dibuat dengan memperhatikan sejauhmana pergerakan korporasi dalam tindak pidana pencucian uang, dengan mempertimbangkan akibat yang ditimbulkan dari kejahatan tersebut, disamping itu sedapat mungkin formulasi mengenai pertanggungjawaban pidana korporasi berkesesuaian dengan KUHP sebagai ketentuan umum.

3. Dalam rangka menganggulangi kejahatan korporasi dibutuhkan suatu kode etik yang dapat mengatur keberadaan atau eksistendi suatu korporasi.

4. Kebijakan formulasi khususnya mengenai model pertanggungjawaban pidana korporasi harus ditambah 1 (satu) model lagi yaitu pengurus dan korporasi sebagai pembuat dan keduanya harus bertanggungjawab.

5. Segera mengesahkan Rancangan Kitab Undang-Undang Hukum Pidana (RKUHP) yang mengatur korporasi sebagai subjek hukum yang akan berlaku pula bagi tindak pidana pencucian uang (melengkapi UndangUndang No. 08 tahun 2010 tentang Pencegahan dan Pemberantasan Tindak Pidana Pencucian Uang).

6. Sistem pertanggungjawaban pidana korporasi perlu diaplikasikan dalam pola penegakan hukum di Indonesia termasuk bagi perkara tindak pidana pencucian uang. 


\section{DAFTAR PUSTAKA}

\section{A. Buku.}

Barda Nawawi Arief, Bunga Rampai Kebijakan Hukum Pidana (Perkembangan Penyusunan Konsep KUHP Baru), Kencana, Jakarta, 2008.

, Kapita Selekta Hukum Pidana, Penerbit PT Citra Aditya Bakti, Bandung, 2010.

, Kebijakan Legislatif Dalam Penanggulangan Kejahatan Dengan Pidana Penjara, Genta Publishing, Yogyakarta, 2010

Chairul Huda, Dari Tiada Pidana Tanpa Kesalahan Menuju Kepada Tiada Pertanggungjawaban Pidana Tanpa Kesalahan, Prenada Media, Jakarta, 2006.

Dwidja Priyatno, Kebijakan Legislasi Tentang Sistem Pertanggungjawaban Pidana Korporasi di Indonesia, Penerbit CV. Utomo, Bandung, 2004.

Esmi Warrasih Pudji Rahayu, Pranata Hukum Sebuah Telaah Sosiologis, Penerbit PT. Suryandaru Utama, Semarang, 2005.

G. Peter Hoefnagels, The Other Side of Criminology, Kluwer Deventer, Holland, 1973.

Indriyanto Seno Adji, Tindak Pidana Ekonomi, Bisnis dan Korupsi Perbankan,

Program Pascasarjana Magister Ilmu Hukum Universitas Padjadjaran Bandung, 2004.

S.R. Sianturi, Asas-asas Hukum Pidana di Indonesia dan Penerapannya, Penerbit Alumni AHAEM-PTHAEM, Jakarta, 1986.

Satjipto Rahardjo, Ilmu Hukum, Penerbit Alumni, Bandung,1986.

Setiyono, Kejahatan Korporasi Analisis Viktimologis Dan Pertanggungjawaban Korporasi Dalam Hukum Pidana Indonesia, Bayu Media Publishing, Malang, 2005.

\section{B. Peraturan Perundang-undangan.}

Undang-Undang Nomor 15 Tahun 2002 Tentang Tindak Pidana Pencucian Uang.

Undang-Undang Nomor 25 Tahun 2003 Tentang Tindak Pidana Pencucian Uang. 
Undang-Undang Nomor 8 Tahun 2010 Tentang Pencegahan dan Pemberantasan Tindak Pidana Pencucian Uang.

Konsep KUHP Tahun 2013.

The United Nations Convention Against Transnational Organized Crimes Tahun 2000.

The United Nations Convention Against Coruption, 2003.

C. Jurnal, Artikel, Makalah, Majalah, Koran, Internet, dan Lain-lain.

Miranda Risang Ayu, Kedudukan Komisi dan Lembaga Independen Sebagai State Auxiliary Institutions dan Relevansinya dalam Struktur Ketatanegaraan Indonesia, Jurnal PSKN UNPAD Vol.1, Bandung.

Nyoman Serikat Putra Jaya, Bahan Kuliah Pembaharuan Hukum Pidana Magister Ilmu Hukum Undip, Unsoed dan Untag, 2010.

, Bahan Kuliah Sistem Peradilan Pidana (Criminal Justice System), Program Magister Ilmu Hukum UNDIP,Semarang,2010.

, Globalisasi HAM dan Penegakan Hukum, Makalah: disampaikan pada matrikulasi mahasiswa program Magister Ilmu Hukum Undip Tahun 2010, tanggal 18 September 2010.

, Kejahatan Dan Pertanggungjawaban Korporasi, Makalah Bahan Kuliah Magister Ilmu Hukum UNDIP.

Yunus Husein, Peran PPATK Dalam Mendeteksi Pencucian Uang, Makalah: Disampaikan pada acara Video Confrence Nasional yang diselenggarakan oleh Pusat Pelaporan dan Analisis Transaksi Keuangan (PPATK), Bank Indonesia, Universitas Indonesia, Universitas Gadjah Mada, Universitas Sumatera Utara, Universitas Diponegoro, Universitas Airlangga, pada tanggal 18 Mei 2004 di gedung Pasca Sarjana Fakultas Hukum Universitas Indonesia. 